\title{
The Effect of Earnings Management on the Probability of Fraud and Financial Distress
}

\author{
Arief Kurniawan ${ }^{1}$, Ancella Anitawati Hermawan*1 \\ ${ }^{1}$ Faculty of Economics and Business, Universitas Indonesia, Depok 16424, Indonesia \\ *ancella_hermawan@yahoo.com
}

\begin{abstract}
The objective of this research is to examine the effect of earnings management on fraud, and its subsequent influence on the probability of financial distress. Hypothesis testing is conducted using the logistic regression method with a sample of listed companies in Indonesia Stock Exchange from 2009 to 2013. The sample of fraudulent companies is based on sanction decisions of the Indonesian Financial Service Authorities applied from 2009 to 2013. The results of this study show that earnings management increases the probability of fraudulent action. However, this study does not find that the increase in the probability of fraud will also increase the probability of financial distress.
\end{abstract}

Keywords: Earnings management, fraud, financial distress

\section{INTRODUCTION}

An agency relationship is a contract in which one or more persons acting as principals (e.g. shareholders) appoint another person as their agent (e.g. a manager) to perform services for the benefit of the principals, included the delegation of decision-making power to the agent ${ }^{1}$. The financial report plays an important role in this agency relationship since it monitors the implementation of these contracts by the management and determines whether a common goal has been achieved by management and shareholders ${ }^{2}$.

One of the items of financial information provided in the financial statement is profit. Profit is an indicator of success in managing the company ${ }^{3}$ and the earnings figure is one of the measures used in the manager's performance appraisal. Managers are required to produce a certain amount of profit in order to achieve corporate objectives. In presenting the profit figures in the income statement, the manager has discretionary options available, such as determining the depreciation method, the useful life of fixed assets, the determination of revenue recognition, discretionary costs, the amount of allowances for doubtful accounts, and so on. Discretionary costs as reported are therefore determined by the manager. Another action that can be taken by managers in influencing earnings figures in the income statement is earnings management.

Earnings management is the choice by a manager of accounting policy, or actions affecting earnings, to achieve some specific reported-earnings objective ${ }^{4}$. Earnings management actions can include the choice of accounting policies and the real actions taken. However, if taken too far, earnings management efforts will result in misstatements of or the omission of figures, or the removal of notes to financial statements 5 . Actions that either delay cost recognition or accelerate revenue recognition are categorized as earnings management. These activities can occur because the manager seeks to achieve earnings targets agreed in his or her contract with the owner. Managers also want to be awarded bonuses even though their company's performance is poor; therefore, managers are motivated to manipulate company accounting data, for example by recognizing fictitious sales, capitalizing expenses, or failing to perform impairment of inventory and fixed assets. Manipulation of accounting data included in financial reporting constitutes fraud.

Financial statement fraud is a deliberate attempt by corporations to deceive or mislead users of published financial statements, especially investors and creditors, by preparing and disseminating materially misstated financial statements ${ }^{6}$. From this definition it can be inferred that fraudulent financial reporting would be detrimental to users of financial statements on the one hand and profitable to company managers on the other.

Managers who undertake frequent earnings management have a tendency to commit fraud. Previous research ${ }^{7}$ shows that fraudulent firms are more likely to have managed earnings in prior years, and that earnings management in prior years is associated with a higher likelihood that firms meet or beat analyst forecasts or inflate their revenue in order to commit fraud. Further, fraudulent firms are more likely to meet or beat analyst forecasts and inflate revenue compared to non-fraudulent firms, even when there is no evidence of prior earnings management ${ }^{7}$.

In the case of fraud, the reported financial statements have been manipulated by manager ${ }^{5}$. In such cases, the actual condition of the firm may be poor, but the company performance reported by the manager shows the generation of revenue growth and expected levels of profit. For example, if a communication tool producer in the market developed a new technology that was more marketable, then the products of an existing producer might 
become obsolete. As a result, sales would decrease, and inventory would be impaired. Cash inflow would decline due to declining sales but cash outflow would remain static because the company continued to pay the costs incurred. However, if the manager covers up these facts by manipulating financial statements, the company's condition will not improve, and it may, in fact, be damaged or destroyed.

Thus, it can be seen that financial reporting fraud can cause financial distress ${ }^{8}$, but research into the effects of fraud on financial distress are still limited. A previous study ${ }^{9}$ found a relationship between the failure of financial management (financial misconduct) and a decline in the operating performance of companies that had committed fraud. In addition, the decline of a firm's operating performance as a result of its financial misconduct and customer reputational sanctions resulting from fraud can be measured in terms of the increase in selling costs following the detection of the firm's financial misconduct ${ }^{9}$.

\section{LITERATURE REVIEW AND HYPOTHESIS DEVELOPMENT Earnings management and fraud}

Both earnings management and fraud are performed consciously by the manager. Earnings management can be carried out because the choice of accounting policies is down to managers, while fraud is carried out deliberately to benefit managers themselves. The profit management background in the agency relationship is contained in the contract that gives incentives to managers who achieve the targets of the owner, while the background to fraud comprises the financial benefits expected to be obtained by managers.

Prolonged earnings management efforts can result in actions ranging from misstatements or omissions of amounts through to material changes to or removal of explanations from the financial statements ${ }^{5}$. Such actions are intended to deceive financial statement users. The terms used to describe these actions are accounting irregularities and fraudulent financial reporting.

There has been little research into the topic of fraudulent financial reporting in Indonesia ${ }^{10}$. Previous research ${ }^{11}$ using financial ratios to detect fraudulent financial reporting found that of 21 financial ratios, 16 had significant results suggesting fraud. Another study ${ }^{11}$ described that, in terms of the size of the company, total assets in following years of more or less than $30 \%$ of the total assets in the previous year indicate fraud. Another study ${ }^{12}$ used a logistic model to show that several proxy variables in the financial statements, such as growth rate, inventory, and return on assets (ROA), differ between companies that commit fraud and those that do not, indicating that profitability has an effect on the tendency toward fraudulent financial reporting. Furthermore, it was found that the management factor (related parties' transactions, history of previous violations, and founder on the board of directors), motivation (financial difficulties, family ownership, and foreign ownership), opportunities (member of the board of directors and audit costs), and earnings management have a significant effect on fraud in the financial reporting of these companies ${ }^{13}$. Another study ${ }^{14}$ found empirical evidence that CEO education, acquisition strategy, financial leverage and the type of public accounting firm (KAP) does not affect accounting fraud propensity, while the variables age of CEO, composition of assets, size of the company, capital turnover, and audit opinion, significantly affect the tendency toward accounting fraud.

Research into the effect of earnings management on fraud is scarce. However, one study ${ }^{7}$ showed that fraudulent firms are more likely to have managed earnings in previous years, and that earnings management in previous years is associated with a higher likelihood that firms that meet or beat analyst forecasts, or that inflate revenue, are committing fraud. Further, it was found that fraudulent firms are more likely to meet or beat analyst forecasts and inflate revenue than non-fraudulent firms, even when there is no evidence of prior earnings management ${ }^{7}$. This study also shows a higher tendency to commit fraud if the company has operated earnings management in previous years. Based on these studies the following hypothesis can be drawn:

\section{H1: Higher discretionary accruals will increase the probability of fraud.}

\section{Fraud and financial distress}

In general, fraud occurs because of pressure or incentives for cheating where there is an opportunity to commit fraud, and from irregularities in individual behavior ${ }^{8}$. If the company commits fraud and this fraud is discovered by the public, the regulator, investors, media, and society in general, the company and related parties will suffer substantial losses².

The parties impaired by fraud are the company itself, the shareholders, and the auditors. For shareholders, the form of this loss is usually a drastic decrease in stock price. It can be seen that the stock market capitalization of companies that commit fraud are relatively decreased after the company is identified as having committed fraud or when the regulator issues a reprimand for a violation ${ }^{2}$.

Fraud can also be the cause of companies experiencing financial distress ${ }^{8}$. One of the most famous examples is that of Enron. Fraud committed by Enron resulted in the company being sued for bankruptcy ${ }^{15}$.

The general perception is that earnings management is opportunistic, in that managers perform it to maximize 
their utility in an agency relationship to maximize their compensation ${ }^{16}$. It is also stated by a number of researchers ${ }^{2,8,15}$ that fraud by the company can force it into bankruptcy. A previous study ${ }^{9}$ found that there is a relationship between the failure of financial management (financial misconduct) and a decline in the operating performance of companies that commit fraud. Furthermore, the decline in operating performance resulting from financial misconduct is caused by reputational sanctions applied by customers toward companies that commit fraud.

In other words, a decrease in performance of the company because of fraud is an indicator that the company is experiencing financial distress. Fraud is defined in this study as fraudulent financial reporting such as material misstatement or omission of material facts in the presentation and disclosure of financial statements. Based on these studies the following hypothesis can be drawn:

\section{H2: A company that commits fraud will have a higher probability of financial distress than other companies.}

\section{RESEARCH METHODS}

This research was conducted to obtain empirical evidence for the hypothesis that greater discretionary accruals increase the likelihood of fraud, and that fraud causes financial distress. The method used for the former is the logistic regression method, while the method used for the latter is a linear regression method using a dummy variable.

The first research model (Model 1) is used to test the first hypothesis (H1). The dependent variable in Model 1 is the binary variable of whether the company is committing fraud or not. The independent variable in Model 1 is discretionary accruals. The control variables used are profitability, as proxied by ROA, the size of the company, and financial leverage proxied by the ratio of total debt to total assets.

$\ln _{\text {it }}\left(\frac{p}{1-p}\right)$ FRAUD $=\beta_{0}+\beta_{1}$ DISACC $_{\text {it }}+\beta_{2}$ ROA $_{i t}+\beta_{3} L_{V R G}{ }_{i t}+\beta_{4}$ SIZE $_{i t}+e_{i t}$

The second research model (Model 2) is used to test the second hypothesis. The dependent variable in this model is the quantitative measure, the Altman Z-Score. The independent variable used in Model 2 is the binary variable of whether the company is committing fraud or not. Fraud is used as the independent variable in this model, calculated by an equation from the first research model. The control variables are ROA as the proxy for profitability, operating cash flow as the proxy for liquidity, total debt to total assets ratio as the proxy for financial leverage, and the size of the company: Model 2 is as follows:

FINDISTRESS $=\beta_{0}+\beta_{1}$ FRAUD $_{\text {it }}+\beta_{2}$ ROA $_{i t}+\beta_{3}$ LVRG $_{\text {it }}+\beta_{4}$ SIZE $_{i t}+\beta_{5} \mathrm{OCF}_{i t}+e_{i t}$

where FINDISTRESS ${ }_{i t}$ is the Altman Z-Score of firm $i$ in year $t$ FRAUD $_{i t}$ is a dummy variable with a value of 1 for fraud enterprise and otherwise a value of 0 to 1 in year $t$ in Model 1 (P (FRAUD)). In the Model 2 the probability of fraudulent enterprise is value 1 in year $t ; R O A_{i t}$ is the ROA of firm $i$ in year $t ; L^{2} G_{i t}$ is the total debt to total assets ratio of firm $i$ in year $t$; $\mathrm{SIZE}_{i t}$ is the size of the company as given by the natural logarithm of the book value of total assets of the company at the end of the fiscal year. $\mathrm{OCF}_{\text {it }}$ is the operating cash flow of firm $\mathrm{i}$ in year $\mathrm{t}$.

The research model uses a sample of non-financial companies listed on the Indonesia Stock Exchange (BEI) from 2009 to 2013. In this study, 77 companies are categorized as having fraudulent financial statements by the Indonesian Financial Service Authorities (Otoritas Jasa Keuangan (OJK)). Seven companies were excluded from the sample because they did not publish annual financial statements either on the website of the BEI, their company website, the IDX library, or the University of Indonesia's Economics and Business Data Center. These companies with troubled financial statements are pair matched with companies whose financial statements are not problematic. The criteria used to identify the companies are those suggested by Beasley: ${ }^{17}$ selling shares on a national securities exchange similar to the BEI and/or the size of the company being categorized as $+/-30 \%$ of the total assets of troubled companies whose financial statements, the financial statements of the same period. In the study there are 70 pairs of companies whose financial statements have problems paired with 70 companies whose financial statements are not in trouble, i.e. 140 sample companies in total.

The 70 companies are divided into nine industry sectors as classified by the BEI. Table 1 shows that the most numerous sector is trade, services, and investment, amounting to $28.57 \%$ of the total sample. This reflects the dominance of this sector in comparison with other industries listed. The least represented sector is agriculture, at $1.43 \%$ of the total sample. This is because the number of listed companies engaged in the agricultural sector is limited. 
Table 1. Distribution of sample

\begin{tabular}{lcc}
\hline \multicolumn{1}{c}{ Industrial sector } & $\begin{array}{c}\text { Fraudulent } \\
\text { financial statements }\end{array}$ & Percentage \\
\hline Agriculture & 1 & $1.43 \%$ \\
Mining & 11 & $15.71 \%$ \\
Basic industry & 13 & $18.57 \%$ \\
Miscellaneous industry & 3 & $4.29 \%$ \\
Consumer goods & 6 & $8.57 \%$ \\
Property and real estate & 8 & $11.43 \%$ \\
Infrastructure & 8 & $11.43 \%$ \\
Trading, services and investment & 20 & $28.57 \%$ \\
Total sample & 70 & $100 \%$ \\
\hline
\end{tabular}

\section{RESULTS AND DISCUSSION}

Table 2. Regression result of research Model 1

\begin{tabular}{lcrcrl}
\hline & $\begin{array}{c}\text { Exp. } \\
\text { sign }\end{array}$ & Coefficient & $\begin{array}{c}\text { Std. } \\
\text { error }\end{array}$ & z-statistic & Prob. \\
\hline Constant & & -2.632 & 1.664 & 2.502 & 0.057 \\
DISACC & + & 2.631 & 1.208 & 4.745 & $0.015^{* *}$ \\
ROA & - & -6.767 & 2.658 & 6.480 & $* 0.006^{* *}$ \\
& - & -0.005 & 0.648 & 0.000 & 0.497 \\
LVRG & - & 0.164 & 0.117 & 1.952 & $0.081^{*}$ \\
SIZE & + & & 0.1321 & & \\
McFadden & & & & & \\
$\mathrm{R}^{2}$ & & & $69.3 \%$ & & \\
Count $\mathrm{R}^{2}$ & & & & \\
\hline
\end{tabular}

*** significant at level $\alpha=1 \%$; ** significant at level $\alpha=5 \%$; significant at level $\alpha=10 \%$; Observations: 140; FRAUD = companies sanctioned by the OJK; DISCACC = magnitude of discretionary accrual measured by modified Jones model; ROA = amount of net income divided by total assets; SIZE = natural logarithm of companies' total assets book value at the end of fiscal year; LVRG $=$ amount of total debt divided by total assets.

\section{The effect of earnings management on the probability of fraud}

The results of Hypothesis 1 testing indicate that greater discretionary accruals increase the likelihood of fraud. Table 2 shows that the variable DISCACC has a positive and significant coefficient at $\alpha=5 \%$. The coefficient of influence of earnings management having a positive direction indicates that the greater the level of earnings management activities undertaken by the company the greater the likelihood of fraud perpetrated by the company will be. In addition, when the possibility of fraud is higher this indicates that the level of management of company profits will be high or positive. Therefore, it is evident that earnings management has a positive influence on the likelihood of fraud, thus $\mathrm{H} 1$ is confirmed.

These results are consistent with previous research ${ }^{7}$ that showed that earnings management by companies has a significant effect on fraud. These results support a previous study ${ }^{13}$ in stating that companies that perform fraudulent financial reporting perform earnings management. Previous research ${ }^{17}$ also provides evidence that companies tend to perform fraudulent financial reporting when they have the opportunity to perform earnings management, in order to make their performance look more successful to shareholders.

Earnings management practices are carried out by utilizing discretionary accounting policies. However, if earnings management by the company leads to a desire by management to carry this activity too far this can result in misstatements or omissions or to the removal of explanations of numbers from financial statements ${ }^{5}$.

Table 3. Regression result of research Model 2

\begin{tabular}{lcrrrl}
\hline & $\begin{array}{c}\text { Exp. } \\
\text { sign }\end{array}$ & Coefficient & Std. error & $\begin{array}{c}\text { Z- } \\
\text { statistic }\end{array}$ & Prob. \\
\hline Constant & & 3.700 & 3.988 & 0.928 & 0.178 \\
FRAUD & - & -0.464 & 0.965 & -0.481 & 0.316 \\
ROA & + & 14.590 & 3.838 & 3.802 & $0.000^{* * *}$ \\
LVRG & - & -9.986 & 1.014 & -9.847 & $0.000^{* * *}$ \\
SIZE & + & 0.278 & 0.280 & 0.993 & 0.161 \\
OCF & - & -0.453 & 4.101 & -0.110 & 0.456 \\
Adjusted & & & 0.764 & & \\
R $^{2}$ & & & & & \\
p-value & & & 0.000 & & \\
\hline
\end{tabular}

*** significant at level $\alpha=1 \%$; ** significant at level $\alpha=5 \%$; significant at level $\alpha=10 \%$; Observations: 140; FINDISTRESS = financial 
distress based on definition by Altman measured by Altman Z-Score; FRAUD = companies sanctioned by the OJK; DISCACC = magnitude of discretionary accrual measured by modified Jones model; ROA = amount of net income divided by total assets; SIZE = natural logarithm of companies' total assets book value at the end of fiscal year; OCF = amount of operational cash flow divided by total assets.

\section{Effect of earnings management on the probability of financial distress through the probability of fraud}

Hypothesis 2 tests whether companies that commit fraud will have a higher likelihood of financial distress than other companies. Table 3 shows that the FRAUD variable has a negative coefficient but not significant in relation to the Altman Z-Score. The negative coefficient of the influence of fraud indicates that companies that commit fraud can have a lower Altman Z-Score, meaning the likelihood of financial distress at the company will be greater. However, the results of these tests show that fraud does not have a significant effect on the likelihood of financial distress. $\mathrm{H} 2$ is therefore not confirmed.

This study does not support the research ${ }^{9}$ that found a relationship between financial misconduct and a decline in operating performance of companies that commit fraud. Furthermore, the decline in operating performance is a result of financial misconduct that results in reputational sanctions from customers at companies that commit fraud. The results of this study are also inconsistent with a previous study ${ }^{2}$ that states that fraud committed by a company brings significant losses for shareholders and may even lead the company into bankruptcy. The results of this study are also inconsistent with previous research ${ }^{8}$ that states that fraudulent financial reporting can cause the bankruptcy of the company concerned.

The sample companies that commit fraud in this study are those reported by the OJK as violating the Presentation of Financial Statements for Public Company regulations or companies who violated OJK rules more than once in a year in the 2009-2013 period. This study indicates that fraud by the company is not related to the company experiencing financial distress. So, in such cases increased financial distress is caused by other factors.

If the Altman Z-Score, which is a proxy of financial distress, is not determined by the occurrence of fraud this may be because companies which commit fraud at the same time maintain their financial condition in order to stay healthy, by maintaining financial leverage and liquidity at a safe level to avoid financial distress. This study proves that earnings management can increase the likelihood of fraud, meaning that performance management is considered successful and therefore managers who want to acquire a bonus may eventually commit fraud. However, in carrying out such actions management does not sacrifice the survival of the company in the long term.

\section{CONCLUSION}

This study examines whether there is a significant effect of earnings management on the possibility of financial distress through fraud. According to the results, earnings management has a significant positive effect on the likelihood of fraud. This means that earnings management performed by a company will increase the likelihood of fraud. Conversely, the lower the level of earnings management in a company, the less likely the occurrence of fraud. However, fraud does not affect the occurrence of financial distress. This means that fraud is not proven to increase the likelihood of financial distress.

This study provides recommendations to the regulator, in this case the Indonesian Financial Services Authority, in order to add, adjust, or tighten the rules regarding the presentation of financial reporting to create a healthy business environment in Indonesia. As a recommendation for investors in public companies, they should not only consider the reported net income, but also pay attention to other aspects such as cash flow, ability to pay debt, and capital. In addition, companies should undertake careful consideration in determining their policies related to the presentation and disclosure of financial statements, such as the use of accounting policy options and compliance with regulations related to presentation and disclosures of financial statements. Short-term company goals must be balanced against long-term objectives for the sustainability of the company.

There are some limitations to this study that may provide material considerations for further research: (1) the study period is only five years; the study period could be extended by combining existing data with data obtained in the future. With a longer sample period it is expected that the influence of the independent variable on the dependent variable would be better revealed; (2) the definition of financial distress in this study was measured using the Z-Score Altman model, and this is a model created using data from the United States. Further study could use other predictors of financial distress ${ }^{18}$ such as companies that have either one of the following criteria for two consecutive years: negative EBITDA, negative EBIT, and negative earnings before special items.; (3) discretionary accruals in this study were measured using a modified Jones mode ${ }^{17}$; however, there are other models to calculate discretionary accruals ${ }^{19}$ which could be employed in future studies. For example, detection of earnings management can also be performed using the revenue model ${ }^{20}$ (4) only quantitative control variables were used in the study, such as financial leverage, liquidity, profitability, and the size of the company (measured by the natural logarithm of the book value of total assets of the company at the end of the fiscal year). Qualitative variables such as industry and corporate governance categories could also be used as control variables. 


\section{REFERENCES}

[1] M. C. Jensen, W. H. Meckling. Theory of the firm: Managerial behavior, agency costs and ownership structure. Journal of Financial Economics, 3(4) (1976) 305-360.

[2] R. Wardhani. Faktor-faktor penyebab dan konsekuensi dari kecurangan pelaporan keuangan (fraud): Suatu tinjauan teoritis. Unpublished Paper (2009).

[3] D. E. Kieso, J. J. Weygandt, T. D. Warfield. Intermediate Accounting: IFRS Edition. John Wiley \& Sons, New Jersey (2011).

[4] W. R. Scott. Financial Accounting Theory, 5th Edition. Prentice Hall Canada, Ontario (2009).

[5] C. W. Mulford, E. E. Comiskey. Deteksi Kecurangan Akuntansi - The Financial Numbers Game (Translated by A. S Harahap \& Y. D. Anggraeni). Penerbit PPM, Jakarta (2010).

[6] Z. Rezaee. Causes, consequences, and deterence of financial statement fraud. Critical Perspectives on Accounting, 16(3) (2005) 277298.

[7] J. L. Perols, B. A. Lougee. The relation between earnings management and financial statement fraud. Advances in Accounting, 27(1) (2011) 39-53.

[8] M. A. Daniri, A. I. Simatupang. Rekayasa pelaporan keuangan: Isu akuntansi atau governance? Bisnis Indonesia 20 April 2008 , Jakarta (2008).

[9] W. C. Johnson, W. Xie, S. Yi. Corporate fraud and the value of reputations in the product market. Journal of Corporate Finance, 25 (2014) 16-39.

[10] W. Wilopo. Analisis faktor-faktor yang berpengaruh terhadap kecenderungan kecurangan akuntansi: Studi pada perusahaan publik dan badan usaha milik negara di Indonesia. Jurnal Riset Akuntansi Indonesia, 9(3) (2006) 346-366.

[11] K. A. Kaminski, T. S. Wetzel, L. Guan. Can financial ratios detect fraudulent financial reporting? Managerial Auditing Journal, 19(1) (2004) $15-28$.

[12] S. L. Summers, J. T. Sweeney. Fraudulently misstated financial statements and insider trading: an empirical analysis. The Accounting Review, 73(1) (1998) 131-146.

[13] S. Hasnan, R. A. Rahman, S. Mahenthiran. Management predisposition, motive, opportunity, and earnings management for fraudulent financial reporting in Malaysia. SSRN (2008).

[14] R. Soselisa, M. Mukhlasin. Pengaruh faktor kultur organisasi, manajemen, strategik, keuangan, dan auditor terhadap kecenderungan kecurangan akuntansi: Studi pada perusahaan publik di Indonesia. Proceedings of the Simposium Nasional Akuntansi XI, (2008), Pontianak, Indonesia.

[15] E. F. Brigham, M. C. Ehrhardt. Financial Management: Theory and Practice, 13th Edition. Cengage Learning, Boston (2011).

[16] S. V. Siregar, S. Utama. Type of earnings management and the effect of ownership structure, firm size, and corporate-governance practices: Evidence from Indonesia. International Journal of Accounting, 43(1) (2008) 1-27.

[17] P. M. Dechow, R. G. Sloan, A. P. Sweeney. Detecting earnings management. The Accounting Review, 70(2) (1995) $193-225$.

[18] H. D. Platt, M. B. Platt. Understanding differences between financial distress and bankruptcy. Review of Applied Economics, 2(2) (2006), 211-227.

[19] S. P. Kothari, AJ Leone, CE Wasley. Performance matched discretionary accrual measures. Journal of Accounting and Economics, 39(1) (2005) 163-197.

[20] S. R. Stubben. Discretionary revenues as a measure of earnings management. The Accounting Review, 85(2) (2010) 695-717. 